\title{
Improving Students' Participation in Speaking Class Through Think-Pair-Share Technique
}

\author{
Nurmuhammet Kerimov, Dahlan Rais, Endang Setyaningsih \\ English Education Department \\ Teacher Training and Education Faculty \\ Sebelas Maret University of Surakarta
}

Email: nury2006@gmail.com

\begin{abstract}
This study focuses on the implementation of think-pair-share technique in improving students "e participation in a bilingual boarding high school in Central Java. The goals of this study are, (1) to identify how think-pair-share can improve the student participation in speaking class, (2) to identify what problems appear during the application of think-pair-share. I adopted Classroom Action Research (CAR) which requires four steps, namely planning, implementing, observing, and reflecting. The participants are 26 high school students. The methods of data collection are observation, diary, interview, photograph, pre-questionnaire, and post-questionnaire. In analyzing data I used (1) constant comparative technique by Burns (qualitative), (2) Likert scale (quantitative). After analyzing the data, I found out that the change in participation in class was clearly seen and all the responses from the students were positive. Moreover the average score of students ` participation in class increased from 30.69 to 45.42 .
\end{abstract}

Keywords: think-pair-share, student participation, learning activity,

\section{INTRODUCTION}

$\begin{array}{cc}\text { In learning } & \text { English especially } \\ \text { speaking, studentse } & \text { participation is }\end{array}$
required. For Indonesian students who learn English as a second language, oral practice will be very helpful for them in achieving the objective of English learning since the objective of English learning in this country is to improve students ${ }^{\text {ee }}$ communicative competence. The teaching of English is expected to make students to be able to use English to communicate. So, bymakingstudents "practiceto communicate each other as much as they can, teachers need to facilitate them to participate more in the teaching learning process.

Cohen in Rocca (2010: 188) argues that participation is a way to bring students actively into the educational process and to assist in enhancing teaching and bringing life to the classroom. The importance of participation in speaking class is to make the students active during the teaching learning process so that they used to use English to communicate, moreover to improve their communicative competence. Besides, by actively participating in the learning process, the learning process will be more alive.

In the previous Program Pengalaman Lapangan (PPL), I observed some points which indicated that the students lacked of participation. The following are the indicators: 1) the students tend to be quiet when the teacher asked question; 2) the students did not dare to ask questions. 3) the students did not dare to comment or 
give opinions. When the teacher asked whether they had understood the topic or not, a long silence took place in class. No one dared or claimed to make comments or give opinions; 4) the students paid less attention to the teacher. It could be identified by their gestures such as the lack of eye contact; 5) the students did not work on the exercises given by the teacher. During the lesson, they had effort with something else, and when the teacher approached them they just opened the exercise in order to look like they were working on the task; 6) the students were not enthusiastic. The teacher had to force some of them for several times to get the answer of a question. Most of them preferred to keep silent than joining the conversation of the teacher; 7) the students were not accustomed to speak in English. During the class discussion, many students spoke in their mother tongue. Teacher had to remind them many times to speak in English; (8) the students were shy and afraid to make mistakes; and (9) the students talked to each other while their friends were performing; 10) Students did not know what to say during the class discussion. They found difficulties in using appropriate terms or dictions in expressing their opinion.

Considering the problems discussed above, I would like to improve the students ${ }^{\text {ee }}$ participation in speaking through Think-Pair-Share technique. According to Barkley, Cross, and Major (2005:104), Think-Pair-Share is particularly effective as a warm-up for whole class discussion. The "Think" component requires students to stop and reflect before speaking, thus giving them an opportunity to collect and organize their thoughts. The "Pair" and "Share" components encourage learners to compare and contrast their understandings with those of another, and to rehearse their response first in a low-risk situation before going public with the whole class. This opportunity to practice comments first with a peer tends to improve the quality of student contributions and generally increases willingness and readiness to speak in a large group Think-Pair-Share is useful for preparing students to participate more fully and effectively in whole class discussions

Utama, Putra, and Jaya (2013) states that Think Pair Share strategy can guide the students to their prior knowledge background and make the students active in participating classroom discussion. In line with Utama, Putra, and Jaya, Barkley, Cross, and Major (2005:103) argues that think-pair share is useful for preparing students to participate more fully and effectively in whole class discussion. This technique gives students time to think about the topic by themself first, then in the pair section students have an opportunity to discuss the topic with their partner and at last they have opportunity to present their ideas in the whole class discussion. This technique is expected to give students more chance to participate in the learning process. Besides, by using this technique students are expected to speak up in the speaking class.

\section{RESEARCH METHODS}

The method that I use in this paper is action research. There are many definitions of action research. According to Wallace in Burns (1999: 30), "action research is done by systematically collecting data on the everyday practice and analyzing it in order to come to some decisions about what the future practice should be". 
Carr and Kemmis in Burns (1999: 30) support the idea above by defining "action research as a form of collective self reflective inquiry undertaken by participants in social situation in order to improve rationally and justice of their own social or educational practices, as well as their understanding of this practice and the situation in which the practices are carried out".

Besides, Burns R. B in Burns (1999: 30) says that action research is the application of fact finding to practical problem solving in a social situation with a view to improving the quality of action within it, involving the collaboration and co-operation of researchers, practitioners and laymen.

This classroom action research was carried out at a boarding high school in 2014-2015 academic year. The classroom is at the second floor. The class is large, so it has enough places for managing every activity. The research was carried out in November 2014 - December 2014 by think-pair-share technique to improve students ${ }^{\text {ee }}$ participation in speaking class. The data of this research were collected through interview, observation, diary, and photographs.

The studentse participation was scored using scoring rubric of participation. It can be seen in Table 1 .

\section{Table 1. Scoring rubric of participation}

\begin{tabular}{|c|c|}
\hline \multicolumn{2}{|r|}{ Natural desire to participate } \\
\hline Excellent (4) & Student is always voluntarily asks and answers questions, and shares opinion or ideas \\
\hline Good (3) & Student is usually voluntarily asks and answers questions, and shares opinion or ideas \\
\hline Satisfactory (2) & Student is rarely voluntarily asks and answers questions, and shares opinion or ideas \\
\hline Needs Improvement (1) & Student is never voluntarily asks and answers questions, and shares opinion or ideas \\
\hline \multicolumn{2}{|r|}{ Showing confidence } \\
\hline Excellent (4) & $\begin{array}{l}\text { Student is always seems comfortable and maintains eye-contact to the teacher or other } \\
\text { classmates when speaking }\end{array}$ \\
\hline Good (3) & $\begin{array}{l}\text { Student is occasionally seems comfortable and maintains eye-contact to the teacher or } \\
\text { other classmates when speaking }\end{array}$ \\
\hline Satisfactory (2) & $\begin{array}{l}\text { Student is rarely seems comfortable and maintains eye-contact to the teacher or other } \\
\text { classmates when speaking }\end{array}$ \\
\hline Needs Improvement (1) & $\begin{array}{l}\text { Student is never seems comfortable and maintains eye-contact to the teacher or other } \\
\text { classmates when speaking }\end{array}$ \\
\hline \multicolumn{2}{|r|}{ Enjoy contributing to class discussion } \\
\hline Excellent (4) & $\begin{array}{l}\text { Student is always exhibit joy and ease in carrying out activities and doing task in } \\
\text { groups }\end{array}$ \\
\hline Good (3) & $\begin{array}{l}\text { Student is occasionally exhibit joy and ease in carrying out activities and doing task in } \\
\text { groups }\end{array}$ \\
\hline Satisfactory (2) & Student is rarely exhibit joy and ease in carrying out activities and doing task in groups \\
\hline Needs Improvement (1) & Student is never exhibit joy and ease in carrying out activities and doing task in groups \\
\hline \multicolumn{2}{|r|}{ Spontaneity } \\
\hline Excellent (4) & $\begin{array}{l}\text { Student is almost never takes long time to think and fluently answers questions and } \\
\text { shares his ideas }\end{array}$ \\
\hline Good (3) & $\begin{array}{l}\text { Student is rarely takes long time to think and fluently answers questions and shares his } \\
\text { ideas }\end{array}$ \\
\hline Satisfactory (2) & $\begin{array}{l}\text { Student is usually takes long time to think and fluently answers questions and shares } \\
\text { his ideas }\end{array}$ \\
\hline Needs Improvement (1) & Student is almost takes long time to think and fluently answers questions and shares his \\
\hline
\end{tabular}




\begin{tabular}{cl}
\hline & ideas \\
\hline & \multicolumn{1}{c}{ Exhibit focus } \\
\hline Excellent (4) & Student is never distracted and stays on the task or class activity all of the time \\
\hline Good (3) & $\begin{array}{l}\text { Student is occasionally distracted and stays on the task or class activity most of the } \\
\text { time }\end{array}$ \\
\hline Satisfactory (2) & Student is rarely distracted and stays on the task or class activity some of the time \\
\hline Needs Improvement (1) & Student is always distracted and hardly ever stays on the task or class activity \\
\hline
\end{tabular}

From the table above, it can be seen that the studentse participation was scored based on their consistency. The maximum score is 4 and the minimum is 1 . I used checklist to observe participation of each student in every meeting.

\section{RESEARCH FINDINGS AND DISCUSSIONS}

Observations revealed some points which indicated the lack of participation and its causes. The following are the indicators: 1) the students tend to be quiet when the teacher asked question; 2) the students did not dare to ask questions. 3) the students did not dare to comment or give opinions. When the teacher asked whether they had understood the topic or not, a long silence took place in class. No one dared or claimed to make comments or give opinions; 4) the students paid less attention to the teacher. It could be identified by their gestures such as the lack of eye contact; 5) the students did not work on the exercises given by the teacher. During the lesson, they had effort with something else, and when the teacher approached them they just opened the exercise in order to look like they were working on the task; 6) the students were not enthusiastic. The teacher had to force some of them for several times to get the answer of a question. Most of them preferred to keep silent than joining the conversation of the teacher; 7) the students were not accustomed to speak in English.
During the class discussion, many students spoke in their mother tongue. Teacher had to remind them many times to speak in English; (8) the students were shy and afraid to make mistakes; and (9) the students talked to each other while their friends were performing; 10) Students did not know what to say during the class discussion. They found difficulties in using appropriate terms or dictions in expressing their opinion.

These problem indicators are caused by some factors. The first cause is the teaching materials. The materials that were used in class no longer interesting and under the level of students. For example the topics like: talking about childhood or conversations about junior high school bored the students. Students demanded fresh topics that is related to their life and current life style.

The second cause is because the students were shy or lack of self confidence. When the teacher asked them to perform most of them are afraid to do it. They were afraid to make mistake while performing in front of their friends.

The third cause is that sometimes the students did not feel well. They were ill, sick or sleepy during the lesson in classroom. Some of the students responded that they did not feel good while I asked them about their weak condition.

The fourth cause is that the students did not have enough motivation. For example, some students at the back row 
were talking in pairs, and one or two were reading irrelevant books with the lesson. They did not feel like related to the lesson or whether interested in the lesson.

The last cause is that students felt lazy. I saw some students who did not write the tasks which were given by teacher; they preferred to copy from their friend's notebook. It was almost impossible to meet a class without any lazy student. Being lazy is naturally normal, and causes some students to lose their attention.

Before I implemented my actions, I observed the class and conducted the questionnaire. The average of the students ${ }^{\text {ee }}$ score in pre-questionnaire was 30.69. Then, I prepared two cycles, the first consisting of two meetings and the second had two meetings. There was not any change for the worse in any student during the research but there were some students whom it took longer than others to improve in participation.

In the summary of all research findings I come up with the occurrence of the improvement in students 'participation in speaking class through the think-pairshare technique. It is proved by the improvement of students ${ }^{\text {ee }}$ mean score in pre-research and post-research. It can be shown in Table 2.

Table 2. Students" Mean Score of Participation

\begin{tabular}{lcc}
\hline Research & Mean Score & Percentage \\
\hline Pre-research & 30.69 & $51.15 \%$ \\
\hline Post-research & 45.42 & $75.7 \%$ \\
\hline Improvement & 14.73 & $24.55 \%$ \\
\hline
\end{tabular}

The students ${ }^{\text {ee }}$ improvement of participation in speaking class can be seen from the mean score of post-research which was higher than the mean score of pre-research. The mean score of pre-research was 30.69 while the mean score of post-research was 45.42 (the maximum score is 60). The description about the students ${ }^{\text {ee }}$ score improvement of each indicator is shown in Table 3.

Table 3. Students" Improvement of each Indicator

\begin{tabular}{lccccc}
\hline & $\begin{array}{c}\text { Natural } \\
\text { Participation }\end{array}$ & Confidence & $\begin{array}{c}\text { Enjoying } \\
\text { Discussion }\end{array}$ & Spontaneity & Focus \\
\hline Pre-research & 6.35 & 5.77 & 7.15 & 4.19 & 7.23 \\
\hline Post-research & 9.54 & 9.23 & 10 & 7.12 & 9.5 \\
\hline Improvement & 3.19 & 3.46 & 2.85 & 2.93 & 2.27 \\
\hline
\end{tabular}

Beside the scores above, I also observed the students ${ }^{\text {ee }}$ behavior when Think-Pair-Share was implemented in speaking class. The observation carried out in four meetings which is summarized as follows.

In the first meeting, among the 26 students about 5/6 students were willing to answer the questions. Only some of the students asked some questions. I tried to encourage students to participate in class by playing games during the learning process. I also gave some biscuits who brave to answer questions and share their ideas. Only three or four students were joined the teachere $s$ conversation. Most of the students were not listening while others performing. 
They were busy talking about something out of the topic.

In the second meeting, about five or six students were willing to make a comment or share their ideas during the lesson. Some of the students were not excited to work with the exercises. In this meeting, only 7/8 students were spoke English during the discussion. Most of the students still did not gain their confidence to speak English.

In the third meeting, I began with playing physical exercises game. Students were focused more after that activity. All the students paid attention to the teacher and other students who were performing. More than half of the class was brave to talk in English. Students were no more shy or afraid to mistake. Half of the students were taking more time when answer the questions and comments. They did not know what to say during the class.

In the fourth meeting, all the students were confident to ask questions and knew the consequences were good. I prepared special activity for students so that they were freely participating during the learning process. Almost all the students were spoke in English during the activity. All the students were listening while others performing. There were only few students that taking more time when answering the questions and giving the comments.

When implementing the action, I found some advantages and difficulties in implementing TPS technique in the research. As its advantage the strategy was very effective; 1) improving the participation and the achievements of students in class, 2) eliminated dominance in the classroom or pair work, 3) allowed quite students to answer questions or performing in front of the class. However there are some difficulties; it did not work for accuracy and did not ideally increase students ${ }^{\text {ee }}$ spontaneity in speaking English.

The English teaching and learning process had become more interesting. There were various activities that could encourage all students to speak up. The use of games created a nice relaxed atmosphere of teaching and learning. The opportunity to ask and answer questions, work in a group or pair, give feedback, and correct their works trained them to be brave, confident, and mature. As a result, they became more enthusiastic and got better understanding in learning English.

The students did not only do what I asked them to do but also they gave suggestions to me how to create an enjoyable learning. The students started to enjoy the English class. They actively engaged during the teaching and learning process. They became a volunteer without I pointed. They freely asked questions when they did not understand. They were also active in answering questions.

There are many ways to help the students participate in class. TPS technique is one of them. It occurs by making good activities and creating authentic atmosphere in class. Improving the students participation in class through TPS technique is very good technique. And it corresponds with all the principles of teaching English or any other subjects. As the result of the implementation of the TPS technique the participation of the tenth year of high school is improved.

\section{CONCLUSIONS AND SUGGESTIONS}

Based on the findings presented in the previous chapter, two points of conclusion are drawn.

The implementation of think-pair-share in improving students' participation in speaking is successful. It lets students to 
act alive in a non-threatening atmosphere and motivates them to participate and attend the lesson actively in class.

There are three advantages and disadvantages of this technique. As its advantage the strategy was very effective;

1) improving the participation and the achievements of students in class, 2) eliminated dominance in the classroom or pair work, 3) allowed quite students to answer questions or performing in front of the class. To assure the fact, at least the change in students participation scores can be seen. The mean of the prequestionnaire was 30.69 and the mean of the post-questionnaire was 45.42 . However there are two difficulties; it did not work for accuracy and did not ideally increase students ${ }^{\text {ee }}$ spontaneity in speaking English.

From the conclusion above some implication might be elicited. The implications are as follows:

1. The success of implementing TPS to improve students ${ }^{\text {ee }}$ participation might imply that TPS is worth to be implemented in teaching speaking

especially to improve students ${ }^{\text {ee }}$ participation during speaking class. Since it requires a non-threatening atmosphere teachers should not too much interfere in the TPS procedures especially in pair and share stages. The teacher may take a role as a monitor and motivator who control and motivate the students to participate more.

2. Considering the disadvantages of TPS, teacher may collaborate TPS with other technique in order to increase students ${ }^{\text {ee }}$ spontaneity in speaking class.

Considering the efforts, difficulties and the joys I have experienced during the implementation of think-pair-share to improve students` participation in speaking I would like to give some suggestions for teachers, students, and other researchers.

For teachers: Making the students inside class attend and participate in lesson is not an easy task. To make a good planning for carrying out a good English class using Think-Pair-Share. Teachers should also create interesting activities and fun learning situation for the students in order to encourage them to give contribution actively to the lesson. Giving suitable topic to be discussed in groups will be effective to foster their social skill and improve their higher-level of thinking. What is more, reward is sometimes needed to motivate the students to be more active during the lesson. The teachers could apply think-pair-share technique as an option to teach speaking in order to improve the students ${ }^{\text {ee }}$ participation.

To students: The students need to be open-minded in class during all the lessons. They have no any reasons to be shy inside the class and to step back or hesitate to participate in lesson. Moreover, during the English classes they need to understand the significance of English, that the English is a world-wide language, and try to catch and learn more and more everything about English. In order to be successful they need to participate to the lessons and practice and be encouraged and motivated as much as possible.

To researchers: Hopefully, this research can be used as the reference to other researchers to develop new methods of teaching English especially in teaching speaking to improve the students ${ }^{\text {ee }}$ participation. 


\section{BIBLIOGRAPHY}

Barkley, Elizabeth F, et. all. (2005).

Collaborative Learning

Techniques.San Francicso:

Jossy-bass.

Burns, Anne. (2010). Doing Action

Research in English

Language Teaching: A Guide

for Practitioners. New York:

Routledge.

Rocca, Kelly A. (2010). Students

Participation in College

Classroom: An Extended
Multidisciplinary Literature

Review. Communication

Education. Volume 59. No 2.

Utama, et. all. (2013). The effect of Think-

Pair-Share teaching strategy to students" self-confidence and speaking competency of the second grade students of SMPN 6 Singaraja. E-Jurnal Program Pascasarjana Universitas Pendidikan Ganesha. Volume 1 